\title{
Labour Innovativeness and Organizational Productivity: The Case of Lubcon Nigeria Limited
}

\author{
Kadiri Ismaila Bolarinwa, PhD., Aliyu Mustapha Olanrewaju \\ \& Dunmade Emmanuel Olaniyi, PhD
}

Department of Industrial Relations and Personnel Management Faculty of Management Sciences, University of Ilorin, Nigeria. aliyu.om@unilorin.edu.ng

Received: 16.03.2020 Accepted: 20.05.2020

Date of Publication: June, 2020

\begin{abstract}
Understanding employees, their behaviour and their influence on an organization are one of the most significant challenges facing organizations more than ever in today's complex and dynamic environment. It is, therefore, pertinent to examine labour innovativeness and organizational productivity. This study adopted descriptive survey research. The population of the study was 460 employees of Lubcon Nigeria Limited, and Guilford and Flruchter (1973) formula used to determine the sample size of 216 . The study employed a primary source of data collection, and the respondents were staff of various departments of the company. The hypothesis was analyzed through regression analysis to test the formulated hypotheses. The findings reveal that $(\mathrm{R}=0.934, \mathrm{R} 2=0.871,(0.000)<0.5)$. This implies that the model fitted by explained $93.4 \%$ of the variability in organizational productivity. The study concludes that employees' innovativeness has a positive and significant impact on organization performance. Therefore, the study recommends that there should be a favourable environment where employees are allowed to be innovative and contribute to their ideas to achieve higher organizational productivity.
\end{abstract}

Keywords: Innovativeness, Labour, Productivity, Lubcon;

\section{Introduction}

Successful organizations depend on successful and multifaceted products. Therefore, new product planning and development can be described as the lifeblood of any business organization. This point supported by the assertion made by Kotler (2000) that consumer desires and the expects a want and expect a torrent of new and improved products. Since no business can survive without the customer, it is thus becoming increasingly risky for an organization not to innovate as consumers are continuously expecting new and improved products. Continuous 
innovation that aimed at meeting the changing needs of the consumer is one sure way to avert obsolescence and loss of customer confidence in the product of organization. Product development demands the integration of many actors of different knowledge and expertise to develop an acceptable product by the customers (Chux, 2010).

Innovativeness is, therefore, mainly about discretionary extra-role behaviours that go beyond the formal job requirements, and organizations are increasingly dependent on their employees' willingness to go the extra mile (Wolfe, 1994). Therefore, the need for innovative employees to initiate innovation within the organization cannot be overemphasized. Labour innovativeness has been examined through various ways in extant literature (Mumford, 2002). Varadarajan, Srinivasan, Vadakkepatt, Yadav, Pavlou, Krishnamurthy and Krause (2010) asserted that, historically, technological innovations had played a significant role in shaping the businesses landscape.

It reported that Lubcon Limited spends a lot of money hiring and keeping the right set of labour in advancing their organizations.

Understanding employees, their behaviour and their influence on the organization are one of the most significant challenges facing organizations more than ever in today's complex and dynamic environment. It is, therefore, pertinent to examine labour innovativeness and organizational productivity in the said organization.

The business will need to have the right set of employees who are well motivated for innovativeness to take place. To this extent, there is a need for organizations to embark on product planning and development as a means to attain a competitive advantage over competitors. In other words, the competitive nature of some organizations requires that managers introduce new products to keep up with rivals, as the high rate of failure in many organizations can be attributed to insufficient labour innovativeness. This study, therefore, seeks to examine the impact of labour innovativeness on organizational productivity;

\section{Literature Review \\ Conceptual Clarifications}

Innovation is the application of ideas, concepts and designs to create wealth. It is "the act of introducing something new". Innovation can also be the process of being creative and implementing new methods to organize or run a company and to create improved results (Ehigie \& McAndrew, 2005). Besides, innovation may be seen as a development of customers' values via the solutions that meet the new undefined or perhaps existing market needs in unique ways. The remedies may include, the new or more effective products, processes, services, technologies or the ideas that are more available to market and the society at large (Alegre, Lapiedra \& Chiva, 2016; Calantone, Harmancioglu, \& Droge, 2010). Labour innovativeness can thus be examıined throughout the innovation process, from initial idea generation to product development, and eventually to product commercialization, or the adoption of new processes or structures in the organization (Axtell, Holman, 
Unsworth, Wall, Waterson\& Harrington 2000, Vincent, decker \& Mumford, 2002).

More importantly, innovativeness usually focuses on the development and successive refinement of inventions into usable products or techniques that are deemed worthy of being launched in a market (Frenz \& Oughton, 2005; Baer, \& Oldham, 2016). There is no universal definition of innovation, and this is attributed to the heterogeneity of sources and outcomes of innovation, which makes it challenging to identify and analyze (Hall, 2005; Brion, 2010). Beaver and Jennings (2014) see innovativeness as production or adoption, assimilation, and exploitation of a value-added novelty in economic and social spheres, renewal and enlargement of products, services, and markets; development of new methods of production; and establishment of new management systems. It is both a process and an outcome.

Innovativeness is, therefore mainly about discretionary extra-role behaviours that go beyond the formal job requirements in complex and ambiguous conditions, and organizations are increasingly dependent on their employees' willingness to go the extra mile (Avermaete et al., 2003; Cadilhon, 2013).

\section{Labour Innovativeness}

The labour innovativeness referring to employees' propensity to innovate can be conceived as complex behaviour consisting of idea generation, idea promotion and idea realization to meet organizational goals in novel ways (Neels \& Kris, 2005; Cooper, 2001;
Cooper \& Kleinschmidt, 2007). Individuals, alone or in groups, undertake innovative activities from the intention to derive anticipated benefits from creative change. Creativity is central to innovativeness, but the concepts are not synonymous. Innovation can be seen as a successful and intentional implementation of creativity, which is more subjective and context-specific by its nature (Avermaete, Viaene, Eleanor \& Crawford, 2003; Charles, 2012). Creativity, as such, may be limited to idea generation alone, but by definition, innovation produces benefits for the people involved in the innovative process (Adams, 2015; Amaratunga \& Baldry, 2011). Therefore, labour innovativeness requires creativity, but creativity does not always lead to innovation.

Trott (2015), labour innovativeness requires that the individual is both able and willing to be innovative. Concerning abilities, above-average general intellect, specific cognitive capabilities, general skills and task and context-specific knowledge, for example, facilitate innovativeness. Beyond knowledge and skills, innovativeness requires intrinsic motivation and a certain level of internal force that pushes the individual to persevere in the face of challenges inherent in the creative work (Wong \& Tong, 2012). Moreover, the internal force keeps the employee going even when the problems are successfully overcome: it is about a positive tension and desire to excel. Consequently, employees' initiative, flexibility, perseverance and willingness to go 
beyond their actual goal accomplishment to come up with novel and organizationally beneficial ideas characterize innovativeness (Goffin \& New, 2001; Bhuiyan, 2011). Often it is impossible to set goals for innovativeness, as it is such a context and problem-specific.

\section{The Innovation Span}

The idea of innovation-span not only clarifies the apparent conflict in the meaning of innovation (Woodcock, Mosey \& Wood, 2000). It can also provide a wider and yet congruent context to all works on innovation, by identifying at the outset, the components of the innovation-span, they are concerned with.

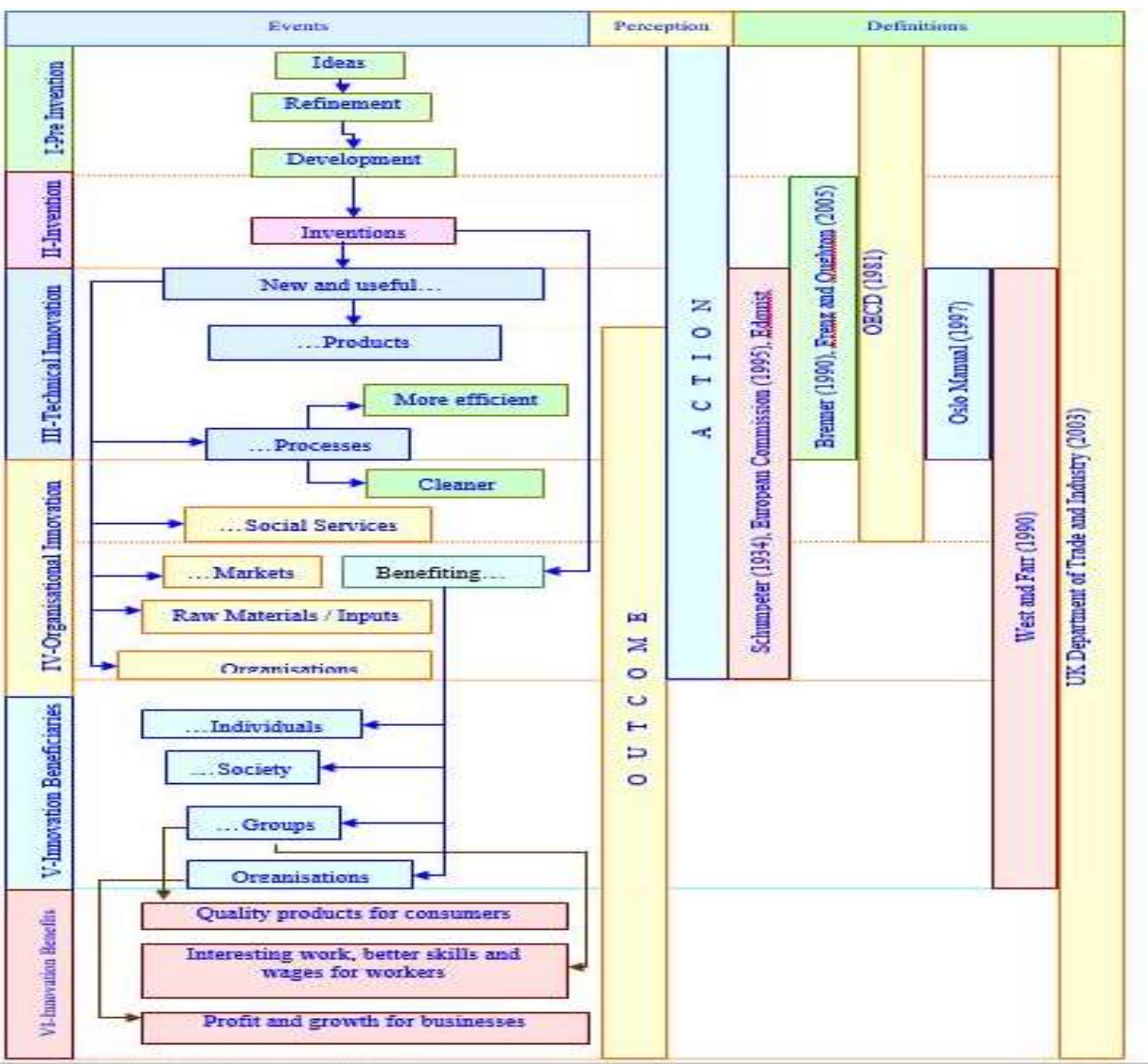

Figure 1: The innovation span

Source: Adapted from Wyld, D.C. (2010). Vijay (2009)

The innovation-span may also provides an instrument to compare the previous studies on the innovation that brings into sharp relif the uselessness of comparison of works concerning non- segments of the innovation-span (Vijay, 2009). Besides, it has the flexibility of incorporating any new sections or components emerging from future work, not included here, by linking them to the URL: http://journals.covenantuniversity.edu.ng/index.php/cjbss 
span at appropriate points (Salan \& Store, 2012; Sandmeier, \& Gassmann, 2010; Seuring, 2008). The utility of the notion of innovation-span becomes evident by the fact that this dissertation concerns segments I, II and III of the innovation-span as it explores the refinement and development of ideas into new and useful products and processes in the organizational productivity.

\section{Theoretical Framework}

\section{Individual Innovativeness Theory}

Rogers gave inspiration to several studies regarding innovation and individual innovativeness (Brandon, 2008; Gillard, Bailey and Nolan, 2008; Jackson, Yi and Park, 2010; Janssen, Van De Vliert and West, 2004; Kilicer and Odabasi, 2010; Yuan and Woodman, 2010 cited in Vijay, 2009). Rogers defines innovation as an idea, practice, or object that is perceived as new by an individual or other unit of adoption (Rogers, 2003). Individual innovativeness defined as developing, adopting or implementing an innovation (Chanal, 2004). Rogers (2003) states that in his own innovativeness theory, there is always new information within the social system and that this further information is processed by adopters (Rogers, 2003).

In the process of adaptation, adopters act upon their perceptions regarding the characteristics of the innovation. Although there are several contextual factors, some findings are influential on adopters' decisions regarding adaptation to innovation. In other words, individuals are likely to have certain perceptions regarding a new technology that they have met in their social environments. These perceptions are quite crucial in terms of innovativeness. It is seen that individuals have different degrees of adaptation to innovation. In general, the population distribution of adaptation to innovation expected to have an almost normal distribution (Husig ad Kohn, 2013). However, Rogers (2003) states that there is no normal distribution due to different determiners such as resistance to technology and material dimension regarding the innovation distribution; that in a society, there are not many innovative individuals; and that there is a bell-shaped distribution.

\section{Empirical Studies}

Empirical research based on the principles and insights presented in this paper was conducted by Sarra, Mehrez and Karim (2014) researched Employee Empowerment and Its Importance for Trust, the study used both primary and secondary sources of data collection and used regression to analyzed the data collected. The main result of the empirical research conducted with a sample of 248 firms belonging to ICT Tunisian sector is that employee empowerment has a positive effect on trust, innovation and organizational productivity.

Eric (2014) in his study, he investigated Enhancing Strategies to Improve Workplace Performance. When employees become dissatisfied at an organization, they may develop negative behaviors that impede profits and productivity. The purpose of this single case study was to explore what strategies are essential for organizational leaders to improve workplace performance. Maslow's 
hierarchy of needs served as the conceptual framework for this study. Data collection involved face-to-face, semi-structured interviews of 20 managers, floor employees, and clerical staff from a business organization in Southwest Georgia. Participant selection based on employees' tenure of at least 1 year of experience within the organization. Interviews were transcribed and coded for common patterns and themes. The study outcomes suggest organizational leaders may increase employee work performance by enhancing strategies that provide a definite assortment of motivational tools and opportunities. Besides, these findings suggest collaborative decision making between management and employees has a positive relationship with work attitudes and the engagement of employees. Leaders in organizations may apply these findings to develop an enriched workplace environment, one that could improve employee retention rates.

\section{Methodology}

This study adopts survey research; this is because it is a method of obtaining research information by asking a set of pre-determined questions from a given sample of individuals drawn from a defined population. The target population comprised of all staff currently employed at Lubcon Nigeria Limited i.e. the senior team, junior staff and the casual workforce. The state chosen for this study was Kwara State for convenience. A total of four hundred and seventy (470) employees were identified as potential respondents.
The sample size was determined by adopting Guilford and Flruchter (1973) formula for estimating sample size:

$$
\frac{\mathrm{N}}{1+\mathrm{Q}^{2} \mathrm{~N}}
$$

Where $\mathrm{N}=$ Population size $=470$

$$
\mathrm{Q}=\text { alpha }=0.05
$$

$$
\begin{array}{ccc}
\mathrm{N} & = & 470 \\
& =216 & \\
1+\mathrm{Q}^{2} \mathrm{~N} & & 1+(0.05)^{2}(470)
\end{array}
$$

A simple random technique was employed to elicit information from 216 respondents. From the list, a sample is drawn, and each person has an equal chance of being drawn during the selection round. This number of 216 respondents is also following the views of Hill, Brierlely and MacDougall (2003), who reported that a sample size of 100 and above is sufficient to present good concise research findings and also provide a good representation of the population or organization or any subject investigated. Primary data were used to test the hypothesis through the use of questionnaires administered to the respondents. The questionnaire was used as a research instrument, which comprises two sections, and sections A contained information on sociodemographic characteristics of the participants; and the section B regarding the view of respondents on labour innovativeness and employees' productivity adapted from Lucio and Alfredo (2011). The study used multiple methods of regression analysis to analyze the data. 


\section{Discussion of Results}

Table 1. Presentation and Analysis of Respondents' Perception of

Labour innovativeness and organizational productivity.

\begin{tabular}{|ll|c|c|c|c|}
\hline & Options & Frequency & Percent & $\begin{array}{c}\text { Valid } \\
\text { Percent }\end{array}$ & $\begin{array}{c}\text { Cumulative } \\
\text { Percent }\end{array}$ \\
\hline Valid & SA & 60 & 31.7 & 31.7 & 31.7 \\
& A & 88 & 46.6 & 46.6 & 78.3 \\
UN & 17 & 9.0 & 9.0 & 87.3 \\
D & 11 & 5.8 & 5.8 & 93.1 \\
SD & 13 & 6.9 & 6.9 & 100.0 \\
Total & 189 & 100.0 & 100.0 & \\
\hline
\end{tabular}

Source: Field Study, 2019

Table 1 posited that $78.3 \%(31.7 \%$ strongly agreed and $46.6 \%$ agreed) constituting the majority of the respondents supported that employees are flexible as they respond well to organizational changes. $9.0 \%$ of the respondents were undecided, and $12.7 \%$ of the respondents $(5.8 \%$ disagreed, and $6.9 \%$ strongly disagreed) did not support.

Table 2: Average productivity of employees has improved over the years

\begin{tabular}{|ll|c|c|c|c|}
\hline & Options & Frequency & Percent & $\begin{array}{c}\text { Valid } \\
\text { Percent }\end{array}$ & $\begin{array}{c}\text { Cumulative } \\
\text { Percent }\end{array}$ \\
\hline Valid & SA & 71 & 37.6 & 37.6 & 37.6 \\
& A & 83 & 43.9 & 43.9 & 81.5 \\
& UN & 10 & 5.3 & 5.3 & 86.8 \\
D & 15 & 7.9 & 7.9 & 94.7 \\
SD & 10 & 5.3 & 5.3 & 100.0 \\
Total & 189 & 100.0 & 100.0 & \\
\hline
\end{tabular}

Source: Field Study, 2019

The Table 2 depicted that $81.5 \%$ (37.6\% strongly agreed and $43.9 \%$ agreed) constituting the majority of the respondents agreed that the average productivity of employees has improved over the years, $5.3 \%$ of the respondents were undecided, and $13.2 \%$ of the respondents $(7.9 \%$ disagreed and $5.3 \%$ strongly disagreed) did not agree. 
Table 3: Idea generation by our employees is at the top priority of the company

\begin{tabular}{|ll|c|c|c|c|}
\hline & Options & Frequency & Percent & $\begin{array}{c}\text { Valid } \\
\text { Percent }\end{array}$ & $\begin{array}{c}\text { Cumulative } \\
\text { Percent }\end{array}$ \\
\hline Valid & SA & 58 & 30.7 & 30.7 & 30.7 \\
& A & 71 & 37.6 & 37.6 & 68.3 \\
& UN & 13 & 6.9 & 6.9 & 75.1 \\
D & 21 & 11.1 & 11.1 & 86.2 \\
SD & 26 & 13.8 & 13.8 & 100.0 \\
Total & 189 & 100.0 & 100.0 & \\
\hline
\end{tabular}

Source: Field Study, 2019

Table 3 indicated that $68.3 \%$ of the respondents $(30.7 \%$ strongly agreed and $37.6 \%$ agreed) which constitute the majority decided that the idea generation by our employees is at the top priority of the company, $6.9 \%$ of the respondents were undecided, and $24.9 \%$ of the respondents $(11.1 \%$ disagreed and $13.8 \%$ strongly disagreed) did support.

Table 4: People are not penalized for new ideas that do not work

\begin{tabular}{|ll|c|c|c|c|}
\hline Options & Frequency & Percent & $\begin{array}{c}\text { Valid } \\
\text { Percent }\end{array}$ & $\begin{array}{c}\text { Cumulative } \\
\text { Percent }\end{array}$ \\
\hline Valid & SA & 73 & 38.6 & 38.6 & 38.6 \\
& A & 84 & 44.4 & 44.4 & 83.1 \\
& UN & 18 & 9.5 & 9.5 & 92.6 \\
D & 8 & 4.2 & 4.2 & 96.8 \\
SD & 6 & 3.2 & 3.2 & 100.0 \\
Total & 189 & 100.0 & 100.0 & \\
\hline
\end{tabular}

Source: Field Study, 2019

Table 4 showed that $83.1 \% \quad(38.6 \%$ strongly agreed and $44.4 \%$ agreed) which made up the majority of the respondents agreed that the people are not penalized for new ideas that do not work, $9.5 \%$ of the respondents were uncertain, and $7.4 \%$ of the respondents
(4.2\% disagreed and $3.2 \%$ strongly disagreed) did not agree.

\section{Test of Hypothesis}

H01: Labour innovativeness does not have a significant impact on organizational productivity. 
Table 5 Model Summary

\begin{tabular}{|c|c|c|c|c|}
\hline Model & $\mathrm{R}$ & $\mathrm{R}$ Square & $\begin{array}{c}\text { Adjusted R } \\
\text { Square }\end{array}$ & $\begin{array}{c}\text { Std. Error of the } \\
\text { Estimate }\end{array}$ \\
\hline 1 & $.934 \mathrm{a}$ & .871 & .866 & .003 \\
\hline
\end{tabular}

Source: Field Study, 2019

a. Predictors: (Constant), Idea generation, idea promotion, idea realization

The coefficient (R) value of 0.934 (93.4\%) indicates the existence of a strong positive impact of labour innovativeness on organizational productivity. The Co-efficient of Determination $\left(\mathrm{R}^{2}\right)$ value of 0.871 $(87.1 \%)$ explains the proportion of the total variations in organizational productivity (Value Added) was accounted for by variations in labour innovativeness. The adjusted $\mathrm{R}^{2}$ value is $0.866(86.6 \%)$, which indicates that the actual variation in organizational productivity (Value Added) could be attributable to $86.6 \%$ of labour innovativeness. It also indicates that labour innovativeness has a significant and positive impact on organizational productivity.

Table 6

ANOVA $^{b}$

\begin{tabular}{|rl|r|r|r|r|r|}
\hline Model & & \multicolumn{1}{|c|}{$\begin{array}{c}\text { Sum of } \\
\text { Squares }\end{array}$} & Df & Mean Square & F & Sig. \\
\hline 1 & Regressi & 200.665 & 2 & 200.665 & 11.325 & $.000^{\mathrm{a}}$ \\
& on & 30.330 & 187 & .162 & & \\
& Residual & 230.995 & 189 & & & \\
\hline
\end{tabular}

Source: Field Study, 2019

a. Predictors: (Constant), Idea generation, idea promotion, idea realization

b. Dependent Variable: Value Added

Table 6 posited that the calculated Pvalue of 0.000 (positive) is less than the tabulated (alpha) value of 0.05 at $95 \%$ level of confidence. Thus, the Null hypothesis, which posits that labour innovativeness does not have a significant impact on organizational productivity, is rejected, while the alternative hypothesis that established that labour innovativeness does have a significant impact on organizational productivity is adopted. This is because the statistical decision rule states that accept the Null hypothesis $\left(\mathrm{H}_{0}\right)$ if the calculated P-value is higher than the

tabulated P-value of 0.05 at $95 \%$ level of confidence; otherwise, reject Null hypothesis $\left(\mathrm{H}_{0}\right)$ and accept the alternative hypothesis. The calculated Fratio of 11.325 , when compared with the tabulated value of 2.344 , indicates that the model is significant because the calculated F-ratio is higher than the tabulated value at $5 \%$ level of significance. Therefore, the alternative hypothesis is adopted, and it could be

URL: http://journals.covenantuniversity.edu.ng/index.php/cjbss 
established that labour innovativeness has a significant impact on

organizational productivity

Table 7

Coefficients $^{\mathbf{a}}$

\begin{tabular}{|c|c|c|c|c|c|c|}
\hline \multirow{2}{*}{\multicolumn{2}{|c|}{ Model }} & \multicolumn{2}{|c|}{$\begin{array}{c}\text { Unstandardized } \\
\text { Coefficients }\end{array}$} & \multirow{2}{*}{\begin{tabular}{|c|}
$\begin{array}{c}\text { Standardized } \\
\text { Coefficients }\end{array}$ \\
Beta \\
\end{tabular}} & \multirow[t]{2}{*}{$\mathrm{t}$} & \multirow[t]{2}{*}{ Sig. } \\
\hline & & B & $\begin{array}{l}\text { Std. } \\
\text { Error }\end{array}$ & & & \\
\hline \multirow[t]{4}{*}{1} & (Constant) & .276 & .057 & & 4.852 & .000 \\
\hline & Idea generatid & 1.442 & 0.34 & .075 & 56.146 & .002 \\
\hline & Idea promotid & 1.665 & 0.44 & .045 & 28.224 & .001 \\
\hline & Idea realizatic & 1.786 & 0.22 & .880 & 35.175 & .000 \\
\hline
\end{tabular}

Source: Field Study, 2019

a. Dependent Variable: Value Added

Table 7 shows the coefficient used in testing whether the three independent variables contributed information to the predictor of the dependent variable "value-added". The t-value in this study was found to be significant at 0.05 levels. All the proxies emerged to be significant (Sig. $\mathrm{t}<0.05$ ) on the independent variables in the regression model. Hence there is a substantial difference between Idea generation, idea promotion, idea realization and organizational productivity.

The result implies that for one additional unit of "idea generation", the value-added, which is the proxy for organizational productivity, increase by $7.5 \%$. This means that the company should take into cognizance the ideas generated by their employees to increase the value-added by employees.

It is also found that the result of "idea promotion" positively impacted on organizational productivity. The result revealed that a unit adoption of "idea promotion" will bring about $4.5 \%$ increase in the value-added and by extension organizational productivity. This is statistically significant at $5 \%$. The result of "idea realization" shows that idea realization positively impacted on organizational productivity. The magnitude of the beta coefficient is statistically significant at $5 \%$ for the sample. The result shows that idea realization impacts on organizational productivity by $88 \%$ for the total sample.

The Hypothesis, which is depicted through the regression analysis with that there is a link between labour innovativeness and organizational productivity. Hence, the null hypothesis was rejected. The results of the analyses indicated that labour innovativeness has a strong positive relationship with organizational productivity. This is because the adjusted $R^{2}$ value of 0.866 $(86.6 \%)$ implies that the actual variation in organizational productivity could be attributable to $86.6 \%$ to labour innovativeness. This finding is in line

URL: http://journals.covenantuniversity.edu.ng/index.php/cjbss 
with that of Sarra, Mehrezand Karim (2014) in where employee empowerment had an impact on organizational productivity. The outcome of this study further indicated a correlation between the variables of employee empowerment, innovation, and organizational productivity, which is further strengthened by the findings of this study.

\section{Conclusion and Recommendations}

The study examined labour innovativeness and organizational productivity. Employees constitute a significant part of an organizational existence in today's society. As the competition among firms in most industries is increasing daily, companies should work towards creating an enabling environment for labour innovativeness. It, therefore, concluded that the level of impact between labour innovativeness and organizational

\section{References}

Adams, A. (2015). Barriers to product innovation in small firms: Policy implications. European Small Business Journal, 1(1), 67-86.

Alegre, J., Lapiedra, R. \& Chiva, R. (2016). A measurement scale for product innovation performance. European Journal of Innovation Management, 9(2), 333.

Ali, Y.; \& Dan, (2003). Complex concurrent engineering and the design structure matrix approach. concurrent engineering: Research and applications. European Journal of Management, 11 (3), 165-177. productivity is very strong, therefore when employees are innovative through idea generation, idea promotion and idea realization, this will result in positive organization performance through higher added value by employees. Further studies should include responses to labour innovative in public organizations. The following recommendations are made:

i) There should be a favourable environment where employees are allowed to be innovative and contribute to their ideas to achieve higher organizational productivity. CEOs should come up with policies that will encourage labour innovativeness.

ii) Employees should be encouraged to contribute their ideas and creativity in every possible and implementable situation to contribute to the organization's productivity.

Amaratunga, D. \& Baldry, B. (2011). Case study methodology as a means of theory building: performance measurement in facilities management organisations. Work Study, 50(3), 95-104.

Avermaete, T. Viaene, J. M.; Eleanor J.\& Crawford, N. (2003). Determinants of Innovation in Small Food Firms.European Journal of Innovation Management, 6,(1), 8-17.

Baer, M., \& Oldham, G. R. (2016). The curilinear relation between experienced creative time pressure and creativity: Moderating effects of openness to experience and support for

URL: http://journals.covenantuniversity.edu.ng/index.php/cjbss 
creativity. Journal of Applied Psychology, 91(3), 963-970.

Beaver, G., \& Jennings, P. L. (2014). Small business, entrepreneurship and enterprise development. Journal of Strategic Change, 9(2), 397-405.

Bhuiyan, N. (2011). A framework for successful new-product development. Journal of Industrial Engineering and Management, 4(4), 746-770.

Brion, S., Mothe, C., \& Sabatier, M. (2010). The impact of organisational context and competences on innovation ambidexterity. International Journal of Innovation Management, 14(2), 151-178.

Cadilhon, J. J. (2013). A conceptual framework to evaluate the impact of innovation platforms onagrifood value chains development. Paper prepared for the 138th EAAE Seminar on Propoor Innovations in Food Supply Chains, Ghent Belgium

Calantone, R. J., Harmancioglu, N., \& Droge, C. (2010). Inconclusive innovation "returns": A metaanalysis of research on innovation in new product development. Journal of Product Innovation Management, 27(7), 1065-1081.

Charles, E. O. (2012). Evaluating New Product Development Performance in Small to Medium Sized Manufacturing Firms. A thesis presented to the University of Western Sydney in partial fulfilment of the requirements for the degree of Doctor of Philosophy
Cooper, R. G., \& Kleinschmidt, E. J. (2007). Winning businesses in product development: the critical success factors. ResearchTechnology Management, 50(3), 52-66.

Cooper, R. (2001). Winning at new products: Accelerating the process from idea to launch. ( $3^{\text {rd }}$ Ed.). Massachusetts: Perseus Publishing.

Cooper, R., \& Edgett, S. (2008). Maximizing productivity in product innovation. Research Technology Management, 51(2), 47-58.

Chanal, V. (2004). Innovation management and organisational learning: adiscursiveapproach.. European Journal of Innovation Management, 7(1), 56-64

Frenz, M. \& Oughton, C. (2005). Innovation in the UK regions and devolved administrations: A Review of the literature. Final Report for the Department of Trade and Industry and the Office of the Deputy Prime Minister

Goffin, K. \& New, C. (2001). Customer support and new product development.International

Journal of Operations \& Production Management, 21(3), pp. 275-301

Husig, G. \& Kohn, T. (2013). Factors influencing the front end of the innovation process: a comprehensive review of selected empirical NPD and explorative ffe studies. Retrieved from https://www.g_scholar.com_1234

Kanter, R. (2008) When a thousand flowers bloom: structural,

URL: http://journals.covenantuniversity.edu.ng/index.php/cjbss 
collective, and social conditions for innovation in organizations, in Research in Organizational Behavior, B.M. Staw and L.L. Cummings, Editors. CT: JAI Press: Greenwich.

Kenneth, B. K. (2013). The PDMA handbook of new product development. ( $3^{\text {rd }}$ ed.). Hoboken, New Jersey: John Wiley \& Sons Inc. p. 21.

Krishnan, V. \& Karl, B. (2001). Product development decisions: A review of the literature. Management Science 47 (1), 1-21.

Kitson, M., J. Michie \& M. Sheehan (2003). Markets, Competition, Cooperation and Innovation.in D. Coffey and C. Thornley (Eds) Industrial and Labour available online www.g_work.org

Kotler, P. \& Armstrong, G. (2010). Principles of marketing. $13^{\text {th }}$ Edition Pearson Education.Inc Upper Saddle River, New Jersey U.S.A.

Lucio, C. \& Alfredo, M. (2011). Strategic innovation and new product development in family firms: An empirically grounded theoretical framework. The current issue and full text archive of this journal is available at www.emeraldinsight.com/13552554.htm

Mary M. C. \& Marina, A. (2010). A multi-dimensional framework of organizational innovation: a systematic review of the literature. Journal of Management Studies 47, 234-243.

Sarra, C.; Mehrez, O. \& Karim, Z. (2014). Do personal characteristics and cultural values that promote innovation, quality, and efficiency compete or complement each other? Journal of Organizational Behavior, 25(2), 175-199

Neels, B.\& Kris, A. (2005). An Assessment of Five Different Theoretical Frameworks to Study the Uptake of Innovations. Paper presented at the 2005 NZARES Conference Tahuna Conference Centre - Nelson, New Zealand. August 26-27, 2005.

Nisula, A. M., \& Kianto, A. (2013). Evaluating and developing innovation capabilities with a structured method. Interdisciplinary Journal of Information, Knowledge, and Management, 8, 59-82. Retrieved from

http://www.ijikm.org/Volume8/IJ IKMv8p059-082Nisula0714.pdf

Ohly, S., \& Fritz, C. (2009). Work characteristics, challenge appraisal, creativity, and proactive behavior: A multi-level stיdx In arnal of Organizational B 70 31(4), 543-565.

Parzefalı, M., Seeck, H. \& Anneli, H. (2008) Labour innovativenessin organizations: a review of the antecedents.Finnish Journal of Business Economics, 2 (08), 165182.

Ramamoor, H. Y. \& Sardessai, R. (2005). Determinants of innovative work behaviour: Development and test of an integrated model. Creativity and Innovation Management, 14(2), 142-150. 
Rogers, C. M. (2003). Regional dimension of innovation: results from the third community innovation survey. International Workshop Empirical Studies on Innovation in Europe, Faculty of Economics, University of Urbino

Riege, A. M. (2003). Validity and reliability tests in case study research: A literature review with "hands-on" applications for each research phase Qualitative Market Research: An International Journal 6 (2), 75 - 86

Eric, C. P. (2014). The Impact of Open Innovation in New Product Development

Process.International Journal of Fundamental Psychology \& Social Sciences. 2(1), 7-12 Available online http://www.fundamentaljournals. org/ijfpss.html

Salan, G. \& Store, Y. J. (2012). Managers' theories about the process of innovation.Journal of Management Studies, 39(2), 147165

Sandmeier, P., M., \& Gassmann, O. (2010). Integrating Customers In Product Innovation: Lessons from industrial development contractors and in-house contractors in rapidly changing customer markets", Journal of Product Innovation Management, 12(3), 200-213
Seuring, S. A. (2008). Assessing the rigor of case study research in supply chain management, Supply Chain Management: $A n$ International Journal, 13(2), 128-137

Trott, P. (2015). Innovation management and new product development. London, Pearson Edu. Ltd.

Vijay, V. (2009). Innovation and new product development by SMEs: An investigation of scottish food and drinks industry. Being a Ph.D Thesis submitted to Edinburgh Napier Business School

West, S. J. \& Hirst, H. (2003). The Scope for the Application of Continuous Improvement to the Process of New Product Development.Brighton, University of Brighton.

Wong, S. K. \& Tong, C. (2012). The influence of market orientation on new product success. European Journal of Innovation Management 15(1), 99-121

Woodcock, D. J., Mosey, S. P. \& Wood, T. B. W. (2000). New product development in British SMEs. European Journal of Innovation Management 3(4), 3-10.

Wyld, D.C. (2010). Speaking up for customers: Can sales professionals spark product innovation? Academy of Management Perspectives, 24(2), 80-82. 